\title{
GROWTH AND MINERAL COMPOSITION OF PAPAYA AND PASSION FRUIT SEEDLINGS IRRIGATED WITH GRAY WATER ${ }^{1}$
}

\author{
HERISON ALVES DE OLIVEIRA ${ }^{2}$, RAFAEL OLIVEIRA BATISTA ${ }^{2}$, FRANCISCO VANIES DA SILVA SÁ2*, \\ NILDO DA SILVA DIAS ${ }^{2}$, ANA KALINE DA COSTA FERREIRA ${ }^{2}$
}

\begin{abstract}
The semi-arid region has long periods of drought, so reusing water is an important alternative to enable irrigated agriculture. The objective of this study was to evaluate the growth and mineral composition of papaya and passion fruit seedlings irrigated with gray water effluents. Two experiments were carried out with papaya and passion fruit seedlings. For nondestructive analyses, the experimental arrangement was in splitplots in time, with plots consisting of three types of irrigation water (gray water effluent; supply water and mixture of gray water and supply water, at 1:1 ratio) and subplots formed by the evaluation times 30,60 and 75 days after sowing, with three replicates and five plants per replicate. For destructive analyses, the experimental arrangement was a simple randomized block design, with three treatments, corresponding to the irrigation waters, with three replicates and five plants per replicate. The seedlings irrigated with gray water effluent had higher values of plant height, stem diameter, length of the largest root, shoot dry mass and root dry mass. N, K, $\mathrm{Ca}, \mathrm{Mg}, \mathrm{Fe}, \mathrm{Mn}$ and $\mathrm{Zn}$ contents in the tissue of papaya seedlings, cv. 'Golden', were not altered by irrigation with gray water effluent. N, Fe and Zn contents in the tissue of passion fruit seedlings, cv. 'Redondo Amarelo', were increased by the application of gray water effluent, while $\mathrm{P}, \mathrm{K}, \mathrm{Ca}, \mathrm{Mg}$ and $\mathrm{Mn}$ contents were not influenced.
\end{abstract}

Keywords: Carica papaya. Passiflora edulis. Water reuse. Fertigation.

\section{CRESCIMENTO E COMPOSIÇÃO MINERAL DE MUDAS DE MAMOEIRO E MARACUJAZEIRO IRRIGADAS COM ÁGUA CINZA}

RESUMO - O semiárido apresenta extensos períodos de seca, com isso, o reúso da água é uma alternativa importante para viabilizar a agricultura irrigada. Objetivou-se com este trabalho avaliar o crescimento e composição mineral de mudas de mamoeiro e maracujazeiro irrigadas com efluentes de água cinza. Dois experimentos foram realizados com mudas de mamoeiro e maracujazeiro. Para as análises não destrutivas, o arranjo experimental foi em parcelas sub-divididas no tempo, sendo dispostos nas parcelas os três tipos de águas de irrigação (efluente de água cinza; água de abastecimento e mistura da água cinza e da água de abastecimento, na proporção 1:1). Na sub-parcela foram distribuídos os tempos de avaliação 30, 60 e 75 dias após a semeadura, com três repetições e cinco plantas por repetição. Para as análises destrutivas, o arranjo experimental foi de blocos casualizados simples, com três tratamentos, correspondentes às águas de irrigação, com três repetições e cinco plantas por repetição. As mudas irrigadas com efluente de água cinza tiveram maiores valores de altura da planta, diâmetro do caule, comprimento da maior raiz, matéria seca da parte aérea e matéria seca da raiz. Os teores de $\mathrm{N}, \mathrm{K}, \mathrm{Ca}, \mathrm{Mg}, \mathrm{Fe}, \mathrm{Mn}$ e $\mathrm{Zn}$ no tecido vegetal das mudas mamoeiro cv. Golden não foram alterados pela irrigação com efluente de água cinza. Os teores de $\mathrm{N}, \mathrm{Fe}$ e $\mathrm{Zn}$ no tecido vegetal das mudas maracujazeiro cv. Redondo Amarelo são incrementados pela aplicação do efluente de água cinza, e os teores de $\mathrm{P}, \mathrm{K}, \mathrm{Ca}, \mathrm{Mg}$ e $\mathrm{Mn}$ não foram influenciados.

Palavras-chave: Carica papaya. Passiflora edulis. Reúso da água. Fertirrigação.

\footnotetext{
${ }^{*}$ Corresponding author

${ }^{1}$ Received for publication in 10/10/2019; accepted in 06/22/2020.

Paper extracted from the doctoral thesis of the first author.

${ }^{2}$ Center of Agrarian Sciences, Universidade Federal Rural do Semi-Árido, Mossoró, RN, Brazil; herisonalves@yahoo.com.br - ORCID: 0000-0002-2751-7785, rafaelbatista@ufersa.edu.br - ORCID: 0000-0002-3083-6808, vanies_agronomia@hotmail.com - ORCID: 00000001-6585-8161, nildo@ufersa.edu.br - ORCID: 0000-0002-1276-5444, klnferreira@ufersa.edu.br - ORCID: 0000-0001-7739-574X.
} 


\section{INTRODUCTION}

Water reuse in agriculture, besides meeting part of the water requirement of plants, can also supply organic matter and nutrients for the development of agricultural crops, contributing to maintain and increase agricultural production throughout the year, especially at the level of family farming, maintaining local workers in rural areas or even leading to this situation (ROCHA et al., 2014; PETOUSI et al., 2018).

Gray water effluents are those without the presence of human feces, are easy to treat and represent about $67 \%$ of the total volume of domestic wastewater generated (CHANAKYA; KHUNTIA, 2014). Thus, gray water has been increasingly used as a source of water in agricultural production, since domestic sewage is available to the farmer every day and, when treated, can promote an increase in the yield and quality of the agricultural product, providing considerable levels of macro- and micronutrients necessary for the development of agricultural crops, besides minimizing the environmental impacts caused by their disposal into the environment (BATISTA et al., 2017).

The Brazilian semi-arid region suffers from water scarcity in terms of quantity, so the incorporation of lower quality waters, such as gray water effluents, is necessary for a successful production in this region, from the stage of seedlings to the stage of production of crops, such as papaya and passion fruit (OLIVEIRA et al., 2015; SÁ et al., 2016).

Papaya (Carica papaya L.) is one of the most important tropical fruit crops in Brazil, for being rich in vitamins $\mathrm{A}$ and $\mathrm{C}$ and antioxidants, thus having a good acceptance in the market (BARROS et al., 2018). This makes the crop attractive to large and small producers, especially in the northeastern region of the country, where it is important for economy and as food, especially in family farming (SÁ et al., 2013; ARAÚJO et al., 2015; SÁ et al., 2016).

Passion fruit (Passiflora edulis $f$. flavicarpa $D e g)$ is a fruit crop of tropical climate, with great economic importance in Brazil, especially in the last two decades, having a high nutritional value (ARAÚJO; FERNANDES; CAMILI, 2017). Family farming found in passion fruit a viable option for production, both technically and economically, contributing to the development of the crop. Until the present, family farming has been responsible for the expansion of commercial orchards (ARAÚJO; FERNANDES; CAMILI, 2017).

Therefore, there is a need to incorporate new technologies that enable and improve the production of these crops, especially in regions affected by low water availability, such as the Brazilian semi-arid region (SÁ et al., 2013; 2014). The objective of this study was to evaluate the growth and mineral composition of papaya and passion fruit seedlings irrigated with gray water effluents.

\section{MATERIAL AND METHODS}

The experiments were carried out in a residence in the rural settlement Jurema, located in the municipality of Mossoró-RN, Brazil, from May to December 2018. The municipality is located in the semi-arid region of northeastern Brazil $(18 \mathrm{~m}$ altitude, $05^{\circ} 1$ ' 41.59" South latitude and $37^{\circ} 19^{\prime}$ 30.38" West longitude) having dry and warm climate, BSwh' type (according to Köppen's classification) (ALVARES et al., 2014). With very irregular rainfall, the municipality has average annual precipitation of $695 \mathrm{~mm}$, average temperature of $27^{\circ} \mathrm{C}$ and average relative air humidity of $70 \%$, with precipitation of $57 \mathrm{~mm}$ in the community during the experiments (INMET, 2019).

For the experiments with papaya and passion fruit, the experimental design was randomized blocks (RBD). For nondestructive analyses, plant height $(\mathrm{PH})$, stem diameter (SD) and number of leaves (NL), the experimental arrangement was in split-plots in time, with plots consisting of three types of irrigation water: GW - gray water effluent; SW - supply water and M - mixture of gray water effluent and supply water, at 1:1 ratio. The subplots contained the evaluation times 30,60 and 75 days after sowing, with three replicates and five plants per replicate.

In the evaluation of the characteristics in destructive tests: length of the largest root (RL), shoot dry mass (SDM), root dry mass (RDM), macronutrients $(\mathrm{N}, \mathrm{P}, \mathrm{K}, \mathrm{Ca}$ and $\mathrm{Mg})$ and micronutrients (Fe, Mn and $\mathrm{Zn}$ ), evaluated only at 75 days, the experimental arrangement was a simple RBD with three treatments, corresponding to the irrigation waters (GW - gray water effluent; SW supply water and $\mathrm{M}$ - mixture of waters at 1:1 ratio), with three replicates and five plants per replicate.

The gray water effluent came from a water treatment system built on the property of a small farmer, located in the settlement. The system started to receive and treat about 60 liters of wastewater from only the showers of two bathrooms, and consisted of: a $0.40 \times 0.40 \times 0.40$ m masonry chamber, which serves as a place for collecting raw gray water; a two-chamber septic tank with capacity of $1000 \mathrm{~L}$ (500 L each chamber); an upward-flow anaerobic filter with a capacity of $500 \mathrm{~L}$; and a reservoir of $500 \mathrm{~L}$ (final reservoir) to store the treated water.

PVC reservoirs of $500 \mathrm{~L}$ each were used for the septic tank, anaerobic filter and final reservoir. For the anaerobic filter, crushed stone no. 1 was used to fill the entire reservoir. A 100-mm-diameter tube was used to divide the two septic tank chambers, 50mm-diameter tubes were used to join the entire system (FERNANDES et al., 2019). 
Papaya plants began to be produced in May 2018, using seeds of papaya (Carica papaya L.), cv. 'Golden'. Passion fruit seedlings began to be produced in August 2018, using passion fruit seeds (Passiflora edulis L.) cv. 'Redondo Amarelo'. The seeds were manually sown in $180-\mathrm{mL}$ disposable cups, by placing only one seed at $1.0 \mathrm{~cm}$ depth in each cup. After 20 days of planting, the seedlings were transplanted to black plastic bags, measuring 15 x $25 \times 0.15 \mathrm{~cm}$ for width, height and thickness, respectively, where they remained until the end of the experiment. The substrate used for planting was produced by the own producer, using a mixture of soil from the region with cattle manure, in a $1: 1$ ratio. Its composition is presented in Table 1.

Table 1. Physicochemical attributes of the substrate used in the production of papaya and passion fruit.

\begin{tabular}{|c|c|c|c|c|c|c|c|c|c|c|c|c|c|}
\hline $\mathrm{N}$ & $\mathrm{pH}$ & EC & $\mathrm{OM}$ & $\mathrm{P}$ & $\overline{\mathrm{K}^{+}}$ & $\mathrm{Na}^{+}$ & $\mathrm{Ca}^{2+}$ & $\mathrm{Mg}^{2+}$ & $\overline{\mathrm{Al}^{3+}}$ & SB & $\mathrm{CEC}$ & $\mathrm{m}$ & ESP \\
\hline $\mathrm{g} \mathrm{kg}^{-1}$ & $\mathrm{H}_{2} \mathrm{O}$ & $\mathrm{dS} / \mathrm{m}$ & $\mathrm{g} \mathrm{kg}^{-1}$ & \multicolumn{6}{|c|}{$\mathrm{mg} \mathrm{dm}^{-3}$} & \multicolumn{2}{|c|}{$\mathrm{cmol}_{\mathrm{c}} \mathrm{dm}^{-3}$} & & $\%$ \\
\hline 3.08 & 7.20 & 1.85 & 25.32 & 407.00 & 254.70 & 128.70 & 11.90 & 7.60 & 0 & 20.71 & 20.71 & 0 & 3.00 \\
\hline
\end{tabular}

$\mathrm{P}, \mathrm{K}^{+}, \mathrm{Na}^{+}$: Mehlich 1 Extractant; $\mathrm{Al}^{3+}, \mathrm{Ca}^{2+}, \mathrm{Mg}^{2+}: 1.0$ mol L ${ }^{-1} \mathrm{KCl}$ extractant; OM: Walkley-Black Wet Digestion; SB Sum of bases; EC - Electrical conductivity; CEC - Total cation exchange capacity; m - Aluminum saturation; ESP Exchangeable sodium percentage.

Irrigation with the different waters (Table 2) started at sowing, with two daily irrigation events, one in the early morning and the other in the late afternoon. Irrigation was performed manually in order to leave the substrate with moisture content close to its maximum water retention capacity. Every five days the maximum water retention capacity was measured using the drainage lysimeter method, and water retention test was performed in three containers of each treatment, to obtain the average. For this, water was gradually added to the substrate with a graduated cylinder containing a volume of 1 $\mathrm{L}$, and the drained water was collected. Thus, the total volume of the cylinder $(1 \mathrm{~L})$ and the drained volume were used to calculate, by difference, the volume retained in the substrate and obtain the maximum water retention capacity.

Table 2. Physicochemical attributes of the waters used in the irrigation of papaya and passion fruit.

\begin{tabular}{|c|c|c|c|}
\hline Attributes $^{1}$ & Supply water & Gray water effluent & Mixture of waters ${ }^{2}$ \\
\hline $\mathrm{pH}$ (water) & 8.20 & 7.90 & 7.90 \\
\hline $\mathrm{EC}\left(\mathrm{ds} \mathrm{m}^{-1}\right)$ & 0.50 & 1.31 & 1.00 \\
\hline $\mathrm{K}^{+}\left(\mathrm{mg} \mathrm{L}^{-1}\right)$ & 21.89 & 31.67 & 27.76 \\
\hline $\mathrm{Na}^{+}\left(\mathrm{mg} \mathrm{L}^{-1}\right)$ & 47.36 & 142.54 & 98.40 \\
\hline $\mathrm{Ca}^{2+}\left(\mathrm{mg} \mathrm{L}^{-1}\right)$ & 93.80 & 77.48 & 97.87 \\
\hline $\mathrm{Mg}^{2+}\left(\mathrm{mg} \mathrm{L}^{-1}\right)$ & 38.89 & 38.89 & 36.46 \\
\hline $\mathrm{Cl}^{-}\left(\mathrm{mg} \mathrm{L}^{-1}\right)$ & 70.90 & 191.43 & 127.62 \\
\hline $\mathrm{HCO}_{3}\left(\mathrm{mg} \mathrm{L}^{-1}\right)$ & 176.96 & 323.41 & 274.59 \\
\hline $\mathrm{CO}_{3}{ }^{2-}\left(\mathrm{mg} \mathrm{L}^{-1}\right)$ & 314.39 & 523.99 & 419.19 \\
\hline $\mathrm{P}\left(\mathrm{mg} \mathrm{L}^{-1}\right)$ & 0.08 & 2.91 & 1.84 \\
\hline $\mathrm{NH}_{4}^{+}\left(\mathrm{mg} \mathrm{L}^{-1}\right)$ & 0.10 & 20.28 & 10.90 \\
\hline $\mathrm{NO}_{3}^{-}\left(\mathrm{mg} \mathrm{L}^{-1}\right)$ & 0.46 & 1.43 & 0.91 \\
\hline $\mathrm{BOD}^{*}\left(\mathrm{mg} \mathrm{L}^{-1}\right)$ & - & 8.00 & 5.00 \\
\hline $\mathrm{COD}^{* *}\left(\mathrm{mg} \mathrm{L}^{-1}\right)$ & - & $<25$ & $<25$ \\
\hline $\operatorname{SAR}\left(\mathrm{mmol}_{\mathrm{c}} \mathrm{L}^{-1}\right)^{0.5}$ & 1.50 & 4.70 & 3.10 \\
\hline $\mathrm{Fe}\left(\mathrm{mg} \mathrm{L}^{-1}\right)$ & $<0.05$ & $<0.05$ & $<0.05$ \\
\hline Total solids $\left(\mathrm{mg} \mathrm{L}^{-1}\right)$ & 54.60 & 913.5 & 474.00 \\
\hline Total dissolved solids $\left(\mathrm{mg} \mathrm{L}^{-1}\right)$ & 53.60 & 904.00 & 468.00 \\
\hline Suspended solids $\left(\mathrm{mg} \mathrm{L}^{-1}\right)$ & 1.00 & 9.00 & 5.00 \\
\hline
\end{tabular}

${ }^{1}$ EC - electrical conductivity; BOD - biochemical oxygen demand; COD - chemical oxygen demand; SAR - sodium adsorption ratio. ${ }^{2}$ Solution obtained from the mixture of gray water effluent with supply water $(1: 1)$.

To verify seedling development, five plants of the plot were evaluated for the following characteristics: a) Height: measured as the distance between the substrate surface and the insertion of the last pair of leaves, using a ruler graduated in centimeter; b) Stem diameter: measured $2 \mathrm{~cm}$ above the substrate surface, using a digital caliper with accuracy of $0.02 \mathrm{~mm}$; c) Number of leaves: quantified by counting the leaves in each of the plants. Measurements were performed at 30, 60 and 75 days after sowing (DAS).

At the end of the 75 days, the length of the largest root of each seedling was measured, from the plant collar to the tip of the root, with a ruler 
graduated in millimeters. Subsequently, the seedlings were taken to the Soil, Water and Plant Analysis Laboratory (LASAP) of the Federal Rural University of the Semi-Arid Region (UFERSA), where the plants were partitioned into leaves, stem and root, placed in paper bags, and dried in a forced air circulation oven at $65{ }^{\circ} \mathrm{C}$ until reaching constant weight. From then on, the dry mass was weighed on an analytical scale with precision of $0.0001 \mathrm{~g}$, to obtain leaf, stem, root and total dry masses.

The dry mass of the leaves of each plant in the plot was ground in a Wiley-type mill. N, P, K, $\mathrm{Ca}, \mathrm{Mg}, \mathrm{Fe}, \mathrm{Mn}$ and $\mathrm{Zn}$ contents were determined by sulfuric digestion $\left(\mathrm{H}_{2} \mathrm{SO}_{4}+\mathrm{H}_{2} \mathrm{O}_{2}\right)$, and the samples were read in an atomic absorption spectrophotometer (AAS) to quantify $\mathrm{Ca}, \mathrm{Mg}, \mathrm{Fe}, \mathrm{Mn}$ and $\mathrm{Zn}$ contents, in the flame photometer to quantify $\mathrm{K}$ content, and in a spectrophotometer by colorimetry to determine $\mathrm{P}$ content, according to the methodology described by EMBRAPA (2009). N content was determined using a nitrogen distiller, according to the methodology cited by Tedesco et al. (1995), with some adaptations of EMBRAPA (2009).

The data obtained were subjected to analysis of variance using the $\mathrm{F}$ test, at $5 \%$ probability level $(p<0.05)$. In case of significant differences were verified between treatments, the data were analyzed by Tukey means comparison test, at $5 \%$ probability level ( $\mathrm{p}<0.05$ ), using the program SISVAR 5.6 (FERREIRA, 2014).

\section{RESULTS AND DISCUSSION}

\section{Experiment 1: Papaya}

The interaction between irrigation waters and times of evaluation of papaya seedlings was significant at $1 \%$ probability level $(p<0.01)$ for the variables plant height $(\mathrm{PH})$ and stem diameter $(\mathrm{SD})$. For the number of leaves (NL), there was a significant effect only of evaluation times, at $1 \%$ probability level $(\mathrm{p}<0.01)$ (Table 3$)$.

Table 3. Summary of the $\mathrm{F}$ test and comparison of means for plant height (PH), stem diameter (SD) and number of leaves (NL) of papaya seedlings irrigated with gray water effluents at different evaluation times.

\begin{tabular}{|c|c|c|c|c|c|c|c|c|c|}
\hline \multirow{2}{*}{ Sources of variation } & \multicolumn{3}{|c|}{ Degrees of freedom } & \multicolumn{6}{|c|}{ Significance of F test } \\
\hline & & & & \multicolumn{2}{|l|}{$\mathrm{PH}$} & \multicolumn{2}{|c|}{ SD } & \multicolumn{2}{|c|}{ NL } \\
\hline Block (B) & \multicolumn{3}{|c|}{2} & \multicolumn{2}{|l|}{0.068} & \multicolumn{2}{|l|}{0.374} & \multicolumn{2}{|c|}{0.460} \\
\hline Water (W) & \multicolumn{3}{|c|}{2} & \multicolumn{2}{|l|}{$0.002 * *$} & \multicolumn{2}{|l|}{$0.002 * *$} & \multicolumn{2}{|c|}{$0.095^{\mathrm{NS}}$} \\
\hline Error $1(\mathrm{~W} * \mathrm{~B})$ & \multicolumn{3}{|c|}{4} & \multicolumn{2}{|l|}{-- } & \multicolumn{2}{|l|}{-- } & \multicolumn{2}{|c|}{--} \\
\hline Time (T) & \multicolumn{3}{|c|}{2} & $0.000 * *$ & & \multicolumn{2}{|l|}{$0.000 * *$} & \multicolumn{2}{|c|}{$0.000^{* *}$} \\
\hline $\mathrm{W} \times \mathrm{T}$ & \multicolumn{3}{|c|}{4} & $0.001 * *$ & & \multicolumn{2}{|c|}{$0.000 * *$} & \multicolumn{2}{|c|}{$0.618^{\mathrm{NS}}$} \\
\hline Error 2 & \multicolumn{3}{|c|}{12} & -- & & \multicolumn{2}{|l|}{--} & \multicolumn{2}{|c|}{-- } \\
\hline \multicolumn{4}{|c|}{ CV1 $(\%)$} & 9.71 & & \multicolumn{2}{|l|}{9.49} & \multicolumn{2}{|c|}{9.38} \\
\hline \multicolumn{4}{|c|}{ CV2 (\%) } & 9.02 & & \multicolumn{2}{|l|}{6.30} & \multicolumn{2}{|c|}{6.17} \\
\hline \multicolumn{3}{|c|}{ Overall mean } & & 26.58 & & \multicolumn{2}{|l|}{5.49} & 12 & \\
\hline & & & Mea & comparis & test & & & & \\
\hline Irrigation waters & & theight (c & & & diameter & & & aber of le & \\
\hline & 30 days & 60 days & 75 days & 30 days & 60 days & 75 days & 30 days & 60 days & 75 days \\
\hline SW & $8.69 \mathrm{a}$ & $22.43 \mathrm{~b}$ & $30.79 \mathrm{~b}$ & $1.85 \mathrm{~b}$ & $5.09 \mathrm{~b}$ & $6.09 \mathrm{c}$ & & & \\
\hline GW & $10.91 \mathrm{a}$ & $32.66 \mathrm{a}$ & $48.15 \mathrm{a}$ & $2.62 \mathrm{a}$ & $7.40 \mathrm{a}$ & $9.30 \mathrm{a}$ & $7.82 \mathrm{C}$ & $13.75 \mathrm{~B}$ & $15.24 \mathrm{~A}$ \\
\hline M & $9.47 \mathrm{a}$ & $31.49 \mathrm{a}$ & $44.70 \mathrm{a}$ & $2.42 \mathrm{ab}$ & $6.74 \mathrm{a}$ & $7.94 \mathrm{~b}$ & & & \\
\hline LSD & & 5.22 & & & 0.75 & & & 0.95 & \\
\hline
\end{tabular}

** = Significant at $1 \%$ probability level; NS $=$ not significant; Lowercase letters in the column compare the decomposition of the plot in each sub-plot and uppercase letters in the row compare the simple effect of the sub-plot. Equal letters do not differ by Tukey test at 5\% probability level; CV1 - Coefficient of variation of the plot; CV2 - Coefficient of variation of the subplot; SW - supply water; GW - gray water effluent and M - mixture of the gray water effluent and supply water, at 1:1 ratio.

For $\mathrm{PH}$ of papaya seedlings at 30 days, there was no significant difference between the studied sources of water. However, at 60 and 75 days after planting, the highest heights were verified in the seedlings irrigated with gray water effluent and with the mixture of the effluent with supply water $(1: 1)$, compared to seedlings irrigated with supply water, with increments on the order of 45.61 and $40.39 \%$ at 60 days and 56.38 and $45.18 \%$ at 75 days after planting, respectively (Table 3 ).

Using supply water in papaya production (cv. Tainung-01), Araújo et al. (2015) observed an average $\mathrm{PH}$ of $19.50 \mathrm{~cm}$ at 60 days after planting. The mean PH found by these authors is close to the 
value found in plants irrigated with supply water $(22.43 \mathrm{~cm})$ and lower than the mean found in seedlings irrigated with gray water effluent and with mixture of waters $(32.66$ and $31.49 \mathrm{~cm})$, obtained in the present study. According to Sá et al. (2013), papaya seedlings must be at least $15-20 \mathrm{~cm}$ tall for transplanting, so it is evident that seedlings irrigated with gray water effluent and mixture of waters were able to be taken to the field before 60 days.

Regarding SD, at 30 days after transplanting, its highest value was obtained using gray water effluent and its lowest value was observed in seedlings irrigated with supply water. At that time, the SD of seedlings irrigated with the mixture of effluent and supply water did not differ from the others. At 60 days, greater diameters were observed in seedlings irrigated with gray water and with the mixture, compared to those irrigated with supply water, with increments on the order of 45.38 and $32.41 \%$, respectively (Table 3 ).

At 75 days, seedlings irrigated with supply water had the lowest means for SD $(6.09 \mathrm{~mm})$. Seedlings irrigated with the mixture of effluent and supply water showed mean values about $30 \%$ higher than that observed in seedlings irrigated with supply water $(7.94 \mathrm{~mm})$, while those irrigated with gray water effluent showed an average of $9.30 \mathrm{~mm}$, which is $52.71 \%$ higher than that for seedlings irrigated with supply water.

Evaluating the production of seedlings of two papaya cultivars in different alternative substrates, Sá et al. (2016) found diameters of $6.97 \mathrm{~mm}$ and $7.73 \mathrm{~mm}$ in the cultivars 'Surinse Solo' and 'Tainung 01 ', respectively, at 60 days after sowing. The results observed by the authors corroborate those of the present experiment observed at 60 days after sowing, indicating that on this date, the seedlings already had a satisfactory diameter to be taken to the field.

For the NL, there was no influence of irrigation water, and significant values were observed only for the evaluation times, with means of 7.82, 13.75 and 15.64 leaves at 30, 60 and 75 days after sowing, respectively (Table 3). Sá et al. (2013) evaluated NL in papaya seedlings in organic hydroponic cultivation as a function of doses and types of bovine biofertilizers, at 60 days after sowing, and found as the best result the production of 10 leaves per plant. Compared to the present study, this number of leaves was exceeded in $37.5 \%$ with the use of gray water effluent, indicating that the domestic effluent, besides meeting the water needs of the plants, has greater potential for substrate fertilization than bovine biofertilizer, probably due to its higher concentration of nitrogen, nutrient directly involved in cell expansion and formation of new tissues (SANTOS et al., 2018).

Using dairy wastewater and two different substrates for papaya cultivation (cv. 'Sunrise Solo'), Santos et al. (2018) noticed that seedlings irrigated with $100 \%$ dairy wastewater showed higher values of PH, SD and NL when compared to those irrigated with diluted effluent. These authors also reported that the increase in growth was proportional to the increase in the percentage of effluent in irrigation water. These results corroborate those observed in the present study, because there was also an increase in the growth of seedlings irrigated with mixture of waters compared to those irrigated with supply water.

At 75 days and in general, the $\mathrm{PH}$ and SD data observed in seedlings irrigated with gray water effluent indicate that it can be used for irrigation of the crop in the seedling stage. This positive effect of gray water is probably due to its greater amount of nutrients. These can accumulate in the substrate after successive irrigations, improving plant performance, since there was no difference in the growth in $\mathrm{PH}$ in the first 30 days after planting (Table 3 ).

Regarding the destructive variables (Table 4), there was a significant effect of the different irrigation waters on root length (RL), root dry mass (RDM) and phosphorus content (P) at $1 \%$ probability level, while shoot dry mass (SDM) was significantly affected at 5\% probability level. Nitrogen $(\mathrm{N})$ and potassium $(\mathrm{K})$ contents in plant tissue were not influenced by the use of gray water effluent.

The seedlings irrigated with gray water effluent showed higher root length (RL) than the others $(29.12 \mathrm{~cm})$, followed by those irrigated with mixture of waters and with supply water (21.39 and $16.53 \mathrm{~cm}$, respectively). Papaya plants irrigated with gray water effluent showed greater root growth (on the order of $76 \%$ ) compared to seedlings irrigated with supply water. Guimarães et al. (2015) studied the production of seedlings of three papaya accessions and doses of the biostimulant $\operatorname{Root}{ }^{\circledR}$ and obtained RL ranging from 18.96 to $23.20 \mathrm{~cm}$. These results indicated that effluent application intensifies root growth. This was also observed in tomato seedlings irrigated with fish farming effluent by Medeiros et al. (2013), who found higher values of RL in seedlings irrigated with effluent compared to those irrigated with supply water. These authors attribute the greater growth of seedlings to the deposition of nutrients in the substrate by the treated effluent, since adequate nutrition favors greater cell expansion and division. 
H. A. OLIVEIRA et al

Table 4. Summary of the F test and comparison of means by Tukey test for root length (RL), shoot dry mass (SDM), root dry mass $(\mathrm{RDM})$, nitrogen $(\mathrm{N})$, phosphorus $(\mathrm{P})$ and potassium $(\mathrm{K})$ in leaves of papaya irrigated with gray water effluent at different evaluation times.

\begin{tabular}{|c|c|c|c|c|c|c|c|}
\hline \multirow{2}{*}{$\begin{array}{c}\text { Sources of } \\
\text { variation }\end{array}$} & \multirow{2}{*}{$\begin{array}{l}\text { Degrees of } \\
\text { freedom }\end{array}$} & \multicolumn{6}{|c|}{ F test } \\
\hline & & $\mathrm{RL}$ & SDM & RDM & $\mathrm{N}$ & $\mathrm{P}$ & $\mathrm{K}$ \\
\hline Block (B) & 2 & 0.129 & 0.094 & 0.443 & 0.794 & 0.167 & 0.360 \\
\hline Waters (W) & 2 & $0.010 * *$ & $0.016^{*}$ & $0.009^{* *}$ & $0.747^{\mathrm{NS}}$ & $0.003^{* *}$ & $0.111^{\mathrm{NS}}$ \\
\hline Error & 4 & -- & -- & -- & -- & -- & -- \\
\hline \multicolumn{2}{|c|}{$\mathrm{CV}(\%)$} & 11.75 & 15.72 & 26.61 & 6.99 & 9.28 & 10.82 \\
\hline \multicolumn{2}{|c|}{ Overall mean } & 22.34 & 2.42 & 0.18 & 37.07 & 1.25 & 22.88 \\
\hline \multicolumn{8}{|c|}{ Means comparison test } \\
\hline Irrigation $\mathrm{w}$ & $\begin{array}{l}\mathrm{RL} \\
(\mathrm{cm})\end{array}$ & $\begin{array}{l}\text { SDM } \\
(\mathrm{g})\end{array}$ & $\begin{array}{c}\mathrm{RDM} \\
(\mathrm{g})\end{array}$ & $\begin{array}{c}\mathrm{N} \\
\left(\mathrm{g} \mathrm{kg}^{-1} \mathrm{DM}\right)\end{array}$ & & DM) & $\begin{array}{c}\mathrm{K} \\
\left(\mathrm{g} \mathrm{kg}^{-1} \mathrm{DM}\right)\end{array}$ \\
\hline SW & $16.53 \mathrm{~b}$ & $1.54 \mathrm{~b}$ & $0.07 \mathrm{~b}$ & 36.52 & & $8 \mathrm{a}$ & 24.98 \\
\hline GW & $29.12 \mathrm{a}$ & $3.15 \mathrm{a}$ & $0.31 \mathrm{a}$ & 38.03 & & $5 \mathrm{~b}$ & 19.70 \\
\hline $\mathrm{M}$ & $21.39 \mathrm{~b}$ & $2.58 \mathrm{ab}$ & $0.18 \mathrm{ab}$ & 36.66 & & $2 b$ & 24.28 \\
\hline LSD & 7.63 & 1.11 & 0.14 & 7.53 & & 33 & 7.23 \\
\hline
\end{tabular}

** and $*=$ Significant at 1 and $5 \%$ probability levels; NS = not significant; Equal letters in the column do not differ by Tukey test at 5\% probability level; CV - Coefficient of variation; SW - supply water; GW - gray water effluent; and M mixture of gray water effluent and supply water, at 1:1 ratio.

Shoot dry mass (SDM) and root dry mass (RDM) showed similar behavior, in which the highest dry mass accumulation was observed in the treatment irrigated with gray water effluent, with mean values of $3.15 \mathrm{~g}$ and $0.31 \mathrm{~g}$, respectively. These results did not differ statistically from those of seedlings irrigated with mixture of waters, with means of $2.58 \mathrm{~g}$ and 0.18 for SDM and RDM, respectively. However, they were $104.5 \%$ and $342.8 \%$ higher than the SDM and RDM accumulations of seedlings irrigated with supply water (Table 4).

Araújo et al. (2015), Lima-Neto et al. (2016) and Sá et al. (2013) found SDM values between 0.5 and $2.01 \mathrm{~g}$ and RDM values between 0.15 and $0.71 \mathrm{~g}$ in papaya seedlings cv. 'Tainung-01' and 'Sunrise Solo' after 60 days, and in the cv. 'Golden' after 90 days of sowing. These authors attributed this variation to different doses of organic matter and, although it was measured after 60 days, the values were lower than the mean found in seedlings irrigated with the treated effluent, but higher than those obtained in seedlings irrigated with supply water, in cases where higher doses of organic matter were applied. This confirms that the best results observed under irrigation with gray water effluent are related to the supply of nutrients from the effluent.

In relation to the mineral composition of plant tissue, the phosphorus (P) content found in seedlings irrigated with supply water (W),
$1.68 \mathrm{~g} \mathrm{~kg}^{-1}$, was higher than those of seedlings irrigated with gray water $\left(1.05 \mathrm{~g} \mathrm{~kg}^{-1}\right)$ and with the mixture $\left(1.02 \mathrm{~g} \mathrm{~kg}^{-1}\right)$, but below the range from 5 to $7 \mathrm{~g} \mathrm{~kg}^{-1}$ recommended by Malavolta, Vitti and Oliveira (1997).

Seedlings irrigated with gray water effluent and with the mixture obtained higher growth and biomass accumulation, and the $\mathrm{P}$ content may have been diluted due to such greater accumulation. This result was also verified by Serrano, Cattaneo and Ferreguetti (2010), because 'Golden' papaya plants accumulate more $\mathrm{P}$ compared to other cultivars, although it showed lower values of plant height, stem diameter, shoot dry mass and root dry mass than the other cultivars.

No significant differences were obtained for the concentrations of $\mathrm{N}$ and $\mathrm{K}$ between the types of water sources studied, with mean values of 37.07 and $22.88 \mathrm{~g} \mathrm{~kg}^{-1}$, respectively (Table 4). The results obtained are slightly below the range described by Malavolta, Vitti and Oliveira (1997) for papaya in the flowering stage, from 40 to $50 \mathrm{~g} \mathrm{~kg}^{-1}$ for $\mathrm{N}$ and from 25 to $30 \mathrm{~g} \mathrm{~kg}^{-1}$ for $\mathrm{K}$, which is due to the juvenile stage of the seedlings.

There was no significant variation in calcium $(\mathrm{Ca})$, magnesium $(\mathrm{Mg})$, iron $(\mathrm{Fe})$, manganese $(\mathrm{Mn})$ and zinc $(\mathrm{Zn})$ contents as a function of irrigation with gray water effluent compared to supply water (Table 5). These results can be explained by the low variation in the content of these nutrients between supply water and gray water effluent (Table 2). 
H. A. OLIVEIRA et al.

Table 5. Summary of the $\mathrm{F}$ test and comparison of means for calcium $(\mathrm{Ca})$, magnesium $(\mathrm{Mg})$, iron $(\mathrm{Fe})$, manganese $(\mathrm{Mn})$ and zinc $(\mathrm{Zn})$ contents in leaves of papaya irrigated with gray water effluent at different evaluation times.

\begin{tabular}{|c|c|c|c|c|c|c|}
\hline \multirow{2}{*}{$\begin{array}{l}\text { Sources of } \\
\text { variation }\end{array}$} & \multirow{2}{*}{$\begin{array}{l}\text { Degrees of } \\
\text { freedom }\end{array}$} & \multicolumn{5}{|c|}{$\mathrm{F}$ test } \\
\hline & & $\mathrm{Ca}$ & $\mathrm{Mg}$ & $\mathrm{Fe}$ & $\mathrm{Mn}$ & $\mathrm{Zn}$ \\
\hline Block (B) & 2 & 0.337 & 0.483 & 0.604 & 0.416 & 0.409 \\
\hline Water $(\mathrm{W})$ & 2 & $0.230^{\mathrm{NS}}$ & $0.388^{\mathrm{NS}}$ & $0.445^{\mathrm{NS}}$ & $0.273^{\mathrm{NS}}$ & $0.600^{\mathrm{NS}}$ \\
\hline Error & 4 & -- & -- & -- & -- & -- \\
\hline \multicolumn{2}{|c|}{ CV $(\%)$} & 8.72 & 6.12 & 14.91 & 8.95 & 16.29 \\
\hline \multicolumn{2}{|c|}{ Overall mean } & 18.78 & 1.71 & 278.45 & 38.16 & 52.48 \\
\hline \multicolumn{7}{|c|}{ Means comparison test } \\
\hline Irrigation waters & $\begin{array}{c}\mathrm{Ca} \\
\left(\mathrm{g} \mathrm{kg}^{-1} \mathrm{DM}\right) \\
\end{array}$ & $\begin{array}{c}\mathrm{Mg} \\
\left(\mathrm{g} \mathrm{kg}^{-1} \mathrm{DM}\right)\end{array}$ & \multicolumn{2}{|c|}{$\begin{array}{c}\mathrm{Fe} \\
\left(\mathrm{mg} \mathrm{kg}^{-1} \mathrm{DM}\right)\end{array}$} & $\begin{array}{c}\mathrm{Mn} \\
\left(\mathrm{mg} \mathrm{kg}^{-1} \mathrm{DM}\right)\end{array}$ & $\begin{array}{c}\mathrm{Zn} \\
\left(\mathrm{mg} \mathrm{kg}^{-1} \mathrm{DM}\right)\end{array}$ \\
\hline SW & 17.70 & \multicolumn{2}{|c|}{1.68} & \multicolumn{2}{|c|}{36.28} & 60.42 \\
\hline GW & 20.35 & \multicolumn{2}{|c|}{1.79} & \multicolumn{2}{|c|}{37.01} & 52.73 \\
\hline M & 18.30 & \multicolumn{2}{|c|}{1.67} & \multicolumn{2}{|c|}{41.21} & 44.31 \\
\hline LSD & 4.76 & \multicolumn{2}{|c|}{0.30} & \multicolumn{2}{|c|}{9.93} & 35.26 \\
\hline
\end{tabular}

** and * = Significant at 1 and $5 \%$ probability levels; NS = not significant; Equal letters in the column do not differ by Tukey test at 5\% probability level; CV - Coefficient of variation; SW - supply water; GW - gray water effluent and M mixture of gray water effluent and supply water, at 1:1 ratio.

The mean contents of calcium $(\mathrm{Ca})$ and magnesium $(\mathrm{Mg})$ were 18.780 .3 and $1.71 \mathrm{~g} \mathrm{~kg}^{-1}$, respectively (Table 5). It can be noted that $\mathrm{Ca}$ contents are above the range observed by Mesquita et al. (2010), from 9.0 to $18.6 \mathrm{~g} \mathrm{~kg}^{-1}$, and that $\mathrm{Mg}$ contents are below the range observed by these authors, from 2.26 to $12.2 \mathrm{~g} \mathrm{~kg}^{-1}$, with values well above that observed in the present study.

The observed mean content of iron $(\mathrm{Fe})$, $278.45 \mathrm{mg} \mathrm{kg}^{-1}$ (Table 5), was close to the value of $259.05 \mathrm{mg} \mathrm{kg}^{-1}$ observed in the cultivar 'Golden' by Serrano, Cattaneo and Ferreguetti (2010), in seedlings irrigated with supply water. Regarding the content of manganese $(\mathrm{Mn})$, a mean value of 38.16 $\mathrm{mg} \mathrm{kg}{ }^{-1}$ was observed (Table 5). These values were lower than those found by Serrano, Cattaneo and Ferreguetti (2010) for the cultivar 'Golden'(74.8 $\mathrm{mg} \mathrm{kg}{ }^{-1}$ ), being below the $70 \mathrm{mg} \mathrm{kg}^{-1}$ recommended by Malavolta, Vitti and Oliveira (1997), which may cause some deficiency in the plant. As for the mean content of zinc $(\mathrm{Zn}), 52.48 \mathrm{mg} \mathrm{kg}^{-1}$ (Table 5), it is within the range from 47 to $66.31 \mathrm{mg} \mathrm{kg}^{-1}$, observed by Mesquita et al. (2010) in papaya cv. 'Baixinho de Santa Amália'.

\section{Experiment 2: Passion Fruit}

According to ANOVA, there is a significant effect of the interaction between water sources and evaluation time $(p<0.05)$ for the variables stem diameter (SD) and number of leaves (NL) of passion fruit seedlings. For plant height $(\mathrm{PH})$, significant effect was only caused by the evaluation times ( $p<$ 0.01) (Table 6).

At 30, 60 and 75 days after planting, the mean values of passion fruit height were 4.87, 13.17 and $38.93 \mathrm{~cm}$, respectively (Table 6). At 60 days after planting, Oliveira et al. (2015) found an average plant height of $9.41 \mathrm{~cm}$ for passion fruit (cv. 'Gigante Amarelo') irrigated with supply water (EC $\left.=0.3 \mathrm{dS} \mathrm{m}^{-1}\right)$ in soil + cattle manure. This height was exceeded by $39.96 \%$, when plants were irrigated with gray water in the same period, indicating that irrigation with gray water effluent improved the growth of yellow passion fruit seedlings.

There were no significant differences for SD at 30 days after planting. However, there were higher values of SD in seedlings irrigated with gray water effluent and mixture of waters at 60 days after planting, with a $10.34 \%$ increase for both irrigation waters. At 75 days, the highest values of diameter were obtained by seedlings irrigated with gray water effluent, with increments of 7.5 and $4.7 \%$ compared to the diameters of seedlings irrigated with supply water and mixture, respectively (Table 6).

The values of SD were similar to those found by Silva et al. (2014), who produced passion fruit seedlings of the same cultivar evaluated in the present study, irrigated with dairy wastewater. These authors noticed an increase in SD proportional to the increase in the percentage of wastewater used, reaching a mean value of $3.13 \mathrm{~mm}$ at 59 days under $100 \%$ wastewater. Freire and Nascimento (2018) evaluated the production of yellow and purple passion fruit seedlings with supply water and fertigation with cattle urine and obtained a mean diameter of $3.3 \mathrm{~mm}$ at 63 days after sowing, corroborating the result observed in the present study. 
H. A. OLIVEIRA et al

Table 6. Summary of the F test and comparison of means for plant height (PH), stem diameter (SD) and number of leaves (NL) of passion fruit seedlings irrigated with gray water effluent at different evaluation times.

\begin{tabular}{|c|c|c|c|c|c|c|c|c|c|}
\hline \multirow{2}{*}{ Sources of variation } & \multirow{2}{*}{\multicolumn{2}{|c|}{ Degrees of freedom }} & \multicolumn{7}{|c|}{ Significance of $F$ test } \\
\hline & & & \multicolumn{3}{|c|}{$\mathrm{PH}$} & \multicolumn{2}{|c|}{ SD } & \multicolumn{2}{|c|}{ NL } \\
\hline Block (B) & \multicolumn{3}{|c|}{2} & 0.095 & & \multicolumn{2}{|l|}{0.374} & \multicolumn{2}{|c|}{0.634} \\
\hline Waters (W) & \multicolumn{3}{|c|}{2} & $0.369^{\mathrm{NS}}$ & & \multicolumn{2}{|l|}{$0.039^{*}$} & \multicolumn{2}{|c|}{$0.287^{\mathrm{NS}}$} \\
\hline Error $1(\mathrm{~W} * \mathrm{~B})$ & \multicolumn{3}{|c|}{4} & -- & & \multicolumn{2}{|l|}{--} & \multicolumn{2}{|c|}{--} \\
\hline Time $(\mathrm{T})$ & \multicolumn{3}{|c|}{2} & $0.000^{* *}$ & & \multicolumn{2}{|l|}{$0.000^{* *}$} & \multicolumn{2}{|c|}{$0.000^{* *}$} \\
\hline $\mathrm{W} \times \mathrm{T}$ & \multicolumn{3}{|c|}{4} & $0.106^{\mathrm{NS}}$ & & \multicolumn{2}{|l|}{$0.031 *$} & \multicolumn{2}{|c|}{$0.022^{*}$} \\
\hline Error 2 & \multicolumn{3}{|c|}{12} & -- & & \multicolumn{2}{|l|}{--} & \multicolumn{2}{|c|}{--} \\
\hline \multicolumn{4}{|c|}{ CV1 $(\%)$} & 11.90 & & \multicolumn{2}{|l|}{4.05} & \multicolumn{2}{|c|}{6.73} \\
\hline \multicolumn{4}{|c|}{ CV2 (\%) } & 12.83 & & \multicolumn{2}{|l|}{2.83} & \multicolumn{2}{|c|}{5.89} \\
\hline \multicolumn{3}{|c|}{ Overall mean } & & 18.98 & & \multicolumn{2}{|l|}{2.93} & \multicolumn{2}{|c|}{9.01} \\
\hline \multicolumn{10}{|c|}{ Means comparison test } \\
\hline \multirow{2}{*}{ Irrigation waters } & & tt height ( & & Ste & diameter & & & nber of le & \\
\hline & 30 Days & 60 days & 75 days & 30 days & 60 days & 75 days & 30 days & 60 days & 75 days \\
\hline SW & & & & $1.60 \mathrm{a}$ & $2.90 \mathrm{~b}$ & $4.00 \mathrm{~b}$ & $5.10 \mathrm{a}$ & $9.50 \mathrm{a}$ & $12.40 \mathrm{ab}$ \\
\hline $\mathrm{GW}$ & $4.87 \mathrm{C}$ & $13.17 \mathrm{~B}$ & $38.93 \mathrm{~A}$ & $1.70 \mathrm{a}$ & $3.20 \mathrm{a}$ & $4.30 \mathrm{a}$ & $5.10 \mathrm{a}$ & $9.01 \mathrm{a}$ & $13.50 \mathrm{a}$ \\
\hline $\mathrm{M}$ & & & & $1.60 \mathrm{a}$ & $3.20 \mathrm{a}$ & $4.10 \mathrm{~b}$ & $5.20 \mathrm{a}$ & $9.50 \mathrm{a}$ & $11.70 \mathrm{~b}$ \\
\hline LSD & & 3.06 & & & 0.18 & & & & \\
\hline
\end{tabular}

** and * = Significant at 1 and 5\% probability levels; NS = not significant; Lowercase letters in the column compare the decomposition of the plot in each sub-plot and uppercase letters in the row compare the simple effect of the sub-plot. Equal letters do not differ by Tukey test at 5\% probability level; CV1 - Coefficient of variation of the plot; CV2 - Coefficient of variation of the subplot; SW- supply water; GW - gray water effluent and M - mixture of gray water effluent and supply water, at $1: 1$ ratio.

The number of leaves (NL) of passion fruit seedlings at 30 and 60 days was not significantly influenced by the irrigation waters, with means of 5.1 and 9.4 leaves per plant, respectively. At 75 days after planting, an increase of $8.87 \%$ was observed in the NL of seedlings irrigated with gray water effluent (13.5 leaves) compared to those irrigated with supply water (Table 6). This result was higher than that found by Cruz et al. (2008), who produced seedlings of yellow passion fruit cv. 'Redondo Amarelo' with $100 \%$ of swine wastewater and obtained an average value of 10.85 leaves per plant.

Regarding the destructive variables (Table 7), there was a significant effect of the different irrigation waters on shoot dry mass (SDM), at $1 \%$ probability level, and on nitrogen $(\mathrm{N})$ content, at $5 \%$ probability level. The variables root length (RL), root dry mass (RDM) and contents of phosphorus (P) and potassium $(\mathrm{K})$ of yellow passion fruit seedlings were not influenced by irrigation with gray water effluent.

The mean value of main root length was not influenced by irrigation, being equal to $21.84 \mathrm{~cm}$ (Table 7). The results obtained for RL are higher than those found by Caproni et al. (2013), who produced yellow passion fruit seedlings with supply water and different doses of nitrogen and found an average value of $17.38 \mathrm{~cm}$ after 120 days of planting.

The highest value of SDM was verified in the treatment irrigated with gray water effluent, averaging $3.34 \mathrm{~g}$. Seedlings that received diluted gray water applications showed intermediate mean value of $2.97 \mathrm{~g}$, while those irrigated with gray water effluent showed mean value of $2.62 \mathrm{~g}$ (Table 7). Seedlings irrigated with gray water effluent showed a $27.48 \%$ increase compared to those irrigated with supply water.

The results were higher than those found by Santos et al. (2017), who produced yellow passion fruit seedlings in a protected environment with supply water and obtained a mean SDM value of $3.12 \mathrm{~g}$ at 70 days after sowing. Berilli et al. (2018) analyzed passion fruit seedlings fertilized with different doses of tannery sludge applied through the leaves and obtained a maximum SDM value of $1.7 \mathrm{~g}$, at 58 days after sowing. Sá et al. (2014) found SDM values at 60 days between 0.71 and $5.36 \mathrm{~g}$, a variation according to different doses of goat mane, showing an increase in SDM with the increase of organic matter in the substrate. These comparisons made it possible to infer that gray water effluent was efficient in the production of passion fruit seedlings, promoting satisfactory dry mass accumulation in their shoots. 
H. A. OLIVEIRA et al

Table 7. Summary of the F test and comparison of means for root length (RL), shoot dry mass (SDM), root dry mass $(\mathrm{RDM})$, nitrogen $(\mathrm{N})$, phosphorus $(\mathrm{P})$ and potassium $(\mathrm{K})$ contents in leaves of passion fruit irrigated with gray water effluent at different evaluation times.

\begin{tabular}{|c|c|c|c|c|c|c|c|}
\hline \multirow{2}{*}{$\begin{array}{c}\text { Sources of } \\
\text { variation }\end{array}$} & \multirow{2}{*}{$\begin{array}{l}\text { Degrees of } \\
\text { freedom }\end{array}$} & \multicolumn{6}{|c|}{ F test } \\
\hline & & $\mathrm{RL}$ & $\overline{\text { SDM }}$ & RDM & $\mathrm{N}$ & $\bar{P}$ & $\bar{K}$ \\
\hline Block (B) & 2 & 0.475 & 0.005 & 0.014 & 0.668 & 0.183 & 0.173 \\
\hline Waters (W) & 2 & $0.599^{\mathrm{NS}}$ & $0.003 * *$ & $0.364^{\mathrm{NS}}$ & $0.048^{*}$ & $0.127^{\mathrm{NS}}$ & $0.618^{\mathrm{NS}}$ \\
\hline Error & 4 & -- & -- & -- & -- & -- & -- \\
\hline \multicolumn{2}{|c|}{$\mathrm{CV}(\%)$} & 10.99 & 3.58 & 5.98 & 6.91 & 8.33 & 9.65 \\
\hline \multicolumn{2}{|c|}{ Overall mean } & 21.84 & 2.97 & 0.46 & 31.37 & 2.35 & 18.51 \\
\hline \multicolumn{8}{|c|}{ Means comparison test } \\
\hline Irrigation $\mathrm{w}$ & $\begin{array}{l}\mathrm{RL} \\
(\mathrm{cm})\end{array}$ & $\begin{array}{c}\text { SDM } \\
(\mathrm{g})\end{array}$ & $\begin{array}{c}\text { RDM } \\
(\mathrm{g})\end{array}$ & (g kई & & $\begin{array}{c}\mathrm{P} \\
\left.\mathrm{g} \mathrm{kg}^{-1} \mathrm{DM}\right)\end{array}$ & $\underset{\left(\mathrm{g} \mathrm{kg}^{-1} \mathrm{DM}\right)}{\mathrm{K}}$ \\
\hline SW & 23.07 & $2.62 \mathrm{c}$ & 0.45 & & & 2.21 & 17.95 \\
\hline GW & 21.14 & $3.34 \mathrm{a}$ & 0.46 & & & 2.60 & 19.38 \\
\hline $\mathrm{M}$ & 21.34 & $2.97 \mathrm{~b}$ & 0.48 & & & 2.27 & 18.21 \\
\hline LSD & 6.98 & 0.30 & 0.08 & & & 0.57 & 5.19 \\
\hline
\end{tabular}

** and $*=$ Significant at 1 and 5\% probability levels; NS = not significant; Equal letters in the column do not differ by Tukey test at 5\% probability level; CV - Coefficient of variation; SW- supply water; GW - gray water effluent and M mixture of gray water effluent and supply water, at 1:1 ratio.

The mean values of RDM were similar for the three types of irrigation water, being equal to $0.46 \mathrm{~g}$ in seedlings irrigated with gray water effluent, $0.48 \mathrm{~g}$ for those irrigated with diluted effluent and $0.45 \mathrm{~g}$ for those irrigated with supply water (Table 7). These values were higher than those found by Caproni et al. (2013) in passion fruit seedlings at 120 days after planting $(0.43 \mathrm{~g})$, but were lower than those observed by Sá et al. (2014) and Medeiros et al (2016) at 60 days after sowing, in seedlings irrigated with supply water and fertilized with goat manure and bovine biofertilizer, thus identifying, better responses of growth and biomass accumulation in the root system as a function of the direct increase of organic matter in the substrate.

Cruz et al. (2008) verified that the use of swine wastewater met the nutritional requirement of passion fruit plants in the initial stage, with no need to supply commercial fertilizers. This result was also observed in the present study, since the mean values of the variables analyzed in seedlings irrigated with gray water effluent were higher than those found in seedlings irrigated with supply water.

Regarding the nutrients in leaf tissue, nitrogen (N) content was higher in seedlings irrigated with gray water, with mean values of $34.30 \mathrm{~g} \mathrm{~kg}^{-1}$ for seedlings irrigated with gray water effluent, $32.08 \mathrm{~g} \mathrm{~kg}^{-1}$ for seedlings irrigated with mixture of waters and $27.74 \mathrm{~g} \mathrm{~kg}^{-1}$ for seedlings irrigated with supply water (Table 7). Although these values are slightly below the range described by Malavolta, Vitti and Oliveira (1997), which is from 40 to $50 \mathrm{~g} \mathrm{~kg}^{-1}$, this higher $\mathrm{N}$ concentration present in gray water probably influenced the formation of new tissues, causing a significant difference in NL values for the types of irrigation water.

Phosphorus (P) and potassium (K) concentrations did not differ significantly between the types of irrigation water, with mean values of 2.35 and $18.51 \mathrm{~g} \mathrm{~kg}^{-1}$, respectively (Table 7). These results are slightly below the ranges described by Malavolta, Vitti and Oliveira (1997) for passion fruit in the production stage, which are from 4 to $5 \mathrm{~g} \mathrm{~kg}^{-1}$ for $\mathrm{P}$ and from 35 to $45 \mathrm{~g} \mathrm{~kg}^{-1}$ for $\mathrm{K}$. This small oscillation below the range may be related to the development stage (seedling stage).

There was a significant difference $(\mathrm{p}<0.05)$ between irrigation waters in the contents of iron $(\mathrm{Fe})$ and zinc $(\mathrm{Zn})$. For the other nutrients, calcium $(\mathrm{Ca})$, magnesium $(\mathrm{Mg})$ and manganese $(\mathrm{Mn})$, no significant variation was observed as a function of the irrigation with gray water effluent (Table 8).

The mean contents of calcium and magnesium observed in passion fruit seedlings were 16.51 and $4.62 \mathrm{~g} \mathrm{~kg}^{-1}$, respectively (Table 8). Ca contents are above the value of $11.1 \mathrm{~g} \mathrm{~kg}^{-1}$ found by Cruz et al. (2008), but $\mathrm{Mg}$ contents are slightly below those found by these authors $\left(5.1 \mathrm{~g} \mathrm{~kg}^{-1}\right)$ in passion fruit seedlings irrigated with $100 \%$ of swine wastewater.

The highest content of iron (Fe), $185.82 \mathrm{mg} \mathrm{kg}^{-1}$, was found in seedlings irrigated with gray water, while the values observed for supply water and mixture did not differ from each other (Table 8). According to Malavolta, Vitti and Oliveira (1997), these values are within the appropriate range for the crop, which is from 120 to $200 \mathrm{mg} \mathrm{kg}{ }^{-1}$. However, the higher Fe content in seedlings irrigated with gray water effluent may be related to their better nutritional status, since Fe is 
the basic constituent of ferredoxin, which has direct action in the electron transport chain in photosystem II, and there was an increase in the nitrogen content of these plants, hence there were probable increments in chlorophyll content and photosynthetic rate (SÁ et al., 2016), which corroborates the greater growth of seedlings irrigated with gray water.

Table 8. Summary of the F test and comparison of means for calcium $(\mathrm{Ca})$, magnesium $(\mathrm{Mg})$, iron $(\mathrm{Fe})$, manganese (Mn) and zinc $(\mathrm{Zn})$ contents in leaves of passion fruit irrigated with gray water effluent at different evaluation times.

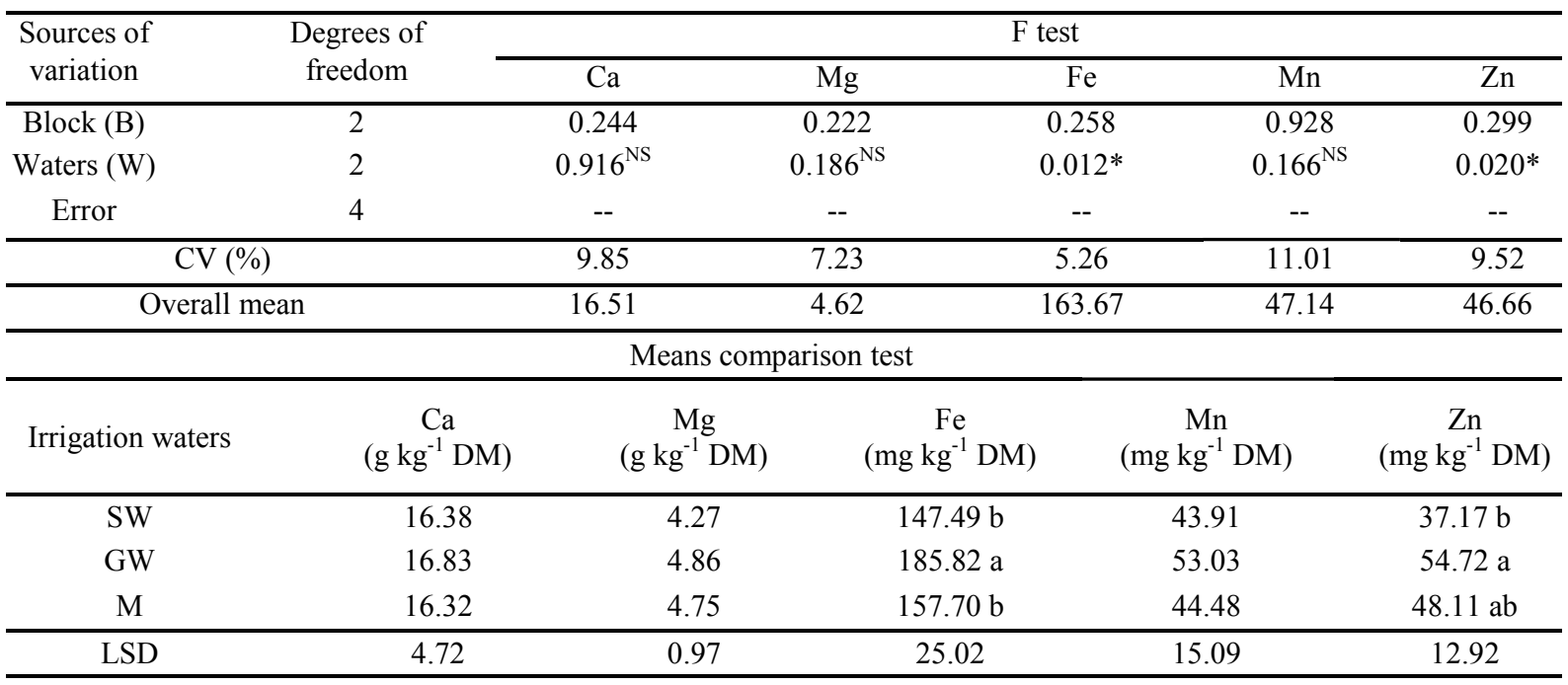

** and $*=$ Significant at 1 and $5 \%$ probability levels; NS $=$ not significant; Equal letters in the column do not differ by Tukey test at 5\% probability level; CV - Coefficient of variation; SW - supply water; GW - gray water effluent and M mixture of gray water effluent and supply water, at 1:1 ratio

The mean content of manganese, 47.14 $\mathrm{mg} \mathrm{kg}^{-1}$ (Table 8), is well below the range of 400 $600 \mathrm{mg} \mathrm{kg}^{-1}$ recommended by Malavolta, Vitti and Oliveira (1997). However, Rodrigues et al. (2009), evaluating the production and mineral nutrition of yellow passion fruit in soil with Supermagro biofertilizer and potassium, obtained a value of 170 $\mathrm{mg} \mathrm{kg}{ }^{-1}$, which is below the range recommended by Malavolta, Vitti and Oliveira (1997), but higher than those observed in the present study, indicating deficiency of this micronutrient.

Regarding the content of zinc ( $\mathrm{Zn}$ ), a higher value was observed in seedlings irrigated with gray water effluent, $54.72 \mathrm{mg} \mathrm{kg}^{-1}$, while mean values of 48.11 and $37.17 \mathrm{mg} \mathrm{kg}^{-1}$ were obtained in seedlings irrigated with mixture of waters and supply water, respectively (Table 8). Zn contents in seedlings irrigated with gray water effluent were higher than those reported by Cruz et al. (2008), who obtained mean value of $38.9 \mathrm{mg} \mathrm{kg}^{-1}$ in seedlings irrigated with $100 \%$ swine wastewater.

In general, irrigation with gray water effluent increased the growth and biomass accumulation of papaya and passion fruit seedlings, promoting more vigorous seedlings compared to those irrigated with supply water. This indicates that this effluent is efficient for the production of fruit crop seedlings in its raw form, with no risk of toxicity to plants. However, there was nutritional divergence between the fruit crops evaluated; for passion fruit, gray water effluent was satisfactory for seedling formation, but papaya seedlings, regardless of the irrigation water used, would require additional supplementation with $\mathrm{P}, \mathrm{Mg}$ and $\mathrm{Mn}$, probably due to their higher nutritional requirement.

Producing Eucalyptus sp. plants with different irrigation waters, Rocha et al. (2014) observed that irrigation with fish farming effluent, supply water and treated domestic effluent led to similar contents of macro- and micronutrients in the leaves, with statistical difference only for nitrogen content. Opposite behavior was observed in the present study, since irrigation with gray water effluent increased the nitrogen, iron, and zinc contents of passion fruit seedlings and was not sufficient to meet the requirements of $\mathrm{P}, \mathrm{Mg}$ and $\mathrm{Mn}$ of papaya seedlings. This result is related to the divergence in the nutritional requirements of each species and denotes that the use of effluents in the irrigation of different species should not be generalized.

\section{CONCLUSIONS}

Irrigation with gray water effluent is viable for the production of papaya and passion fruit seedlings, promoting greater growth and biomass accumulation compared to seedlings irrigated with supply water. 
$\mathrm{N}, \mathrm{K}, \mathrm{Ca}, \mathrm{Mg}, \mathrm{Fe}, \mathrm{Mn}$ and $\mathrm{Zn}$ contents in the tissue of papaya seedlings cv. 'Golden' were not altered by irrigation with gray water effluent.

$\mathrm{N}, \mathrm{Fe}$ and $\mathrm{Zn}$ contents in the tissue of passion fruit seedlings cv. 'Redondo Amarelo' were increased by the application of gray water effluent, while $\mathrm{P}, \mathrm{K}, \mathrm{Ca}, \mathrm{Mg}$ and $\mathrm{Mn}$ contents were not influenced.

\section{REFERENCES}

ALVARES, C. A. et al. Köppen's climate classification map for Brazil. Meteorologische Zeitschrift, 22: 711728,2014

ARAÚJO, E. B. G. et al. Fontes e doses de matéria orgânica na produção de mudas de mamoeiro. Agropecuária Técnica, 36: 264-272, 2015.

ARAÚJO, M. M. V.; FERNANDES, D. Á.; CAMILI, E. C. Emergência e vigor de sementes de maracujá amarelo em função de diferentes disponibilidades hídricas. Uniciências, 20: 82-87, 2017.

BARROS, T. F. S. et al. Qualidade de frutos de cultivares de mamão comercializados em supermercados de Campina Grande-PB. Agropecuária Técnica, 39: 129-142, 2018.

BATISTA, A. A. et al. Qualidade dos frutos de mamoeiro produzidos com esgoto doméstico tratado. Revista Ciência Agronômica, 48: 70-80, 2017.

BERILLI, S. S. et al. Adubação foliar com lodo de curtume líquido no desenvolvimento e qualidade de mudas de maracujá-amarelo. Revista Brasileira de Agricultura Irrigada, 12: 2477-2486, 2018.

CAPRONI, C. M. et al. Substratos e adubação nitrogenada na produção de mudas de maracujazeiro amarelo. Scientia Agraria, 14: 91-97, 2013.

CHANAKYA, H. N.; KHUNTIA, H. K. Treatment of gray water using anaerobic biofilms created on synthetic and natural fibers. Process Safety and Environmental Protection, 92: 186-192, 2014.

CRUZ, M. C. M. et al. Utilização de água residuária de suinocultura na produção de mudas de maracujazeiro-azedo cv Redondo Amarelo. Revista Brasileira de Fruticultura, 30: 1107-1112, 2008.

EMPRESA BRASILEIRA DE PESQUISA AGROPECUÁRIA - EMBRAPA. Manual de análises químicas de solos, plantas e fertilizantes. 2. ed. Brasília, DF: AGEITEC, 2009. 627 p.

FERNANDES, I. R. D. et al. Tratamento de água cinza e reúso no cultivo de girassol ornamental. In: DIAS, N. S. et al. (Eds.). Agricultura familiar e convivência com o semiárido. São Paulo, SP: Livraria da Física, 2019. v. 1, cap. 9, p. 241-256.

FERREIRA, D. F. Sisvar: a Guide for its Bootstrap procedures in multiple comparisons. Ciência Agrotecnologia, 38: 109-112, 2014.

FREIRE, J. L. O.; NASCIMENTO, G. S. Produção de mudas de maracujazeiros amarelo e roxo irrigadas com águas salinas e uso de urina de vaca. Revista de Ciências Agrárias, 41: 111-120, 2018.

GUIMARÃES, I. P. et al. Uso do bioestimulante Root ${ }^{\circledR}$ na produção de mudas de três acessos de mamoeiro. Revista de Ciências Agrárias, 38: 414 $421,2015$.

INSTITUTO NACIONAL DE METEOROLOGIA INMET. Banco de Dados Meteorológicos para Ensino e Pesquisa. Disponível em: <http:// www.inmet.gov.br/portal/>. Acesso em: 21 jan. 2019.

LIMA-NETO, A. J. et al. Papaya seedlings irrigation with saline water in soil with bovine biofertilizer. Chilean Journal of Agricultural Research, 76: 236-242, 2016

MALAVOLTA, E.; VITTI, G. C.; OLIVEIRA, S. A. Avaliação do estado nutricional das plantas: princípios e aplicações. 2. ed. Piracicaba, SP: POTAFOS, 1997. $319 \mathrm{p}$

MEDEIROS, D. C. et al. Qualidade de mudas de tomate em função de diferentes substratos e irrigados com efluentes de piscicultura. Revista Brasileira de Agroecologia, 8: 170-175-175, 2013.

MEDEIROS, S. A. S et al. Água salina e biofertilizante de esterco bovino na formação e qualidade de mudas de maracujazeiro amarelo. Irriga, 21: 779-795, 2016

MESQUITA, E. F. et al. Teores foliares e exportação de nutrientes do mamoeiro Baixinho de Santa Amália tratado com biofertilizantes. Pesquisa Agropecuária Tropical, 40: 1-11, 2010.

OLIVEIRA, F. A. et al. Interação salinidade da água de irrigação e substratos na produção de mudas de maracujazeiro amarelo. Comunicata Scientiae, 6: 471-478, 2015.

PETOUSI, I. et al. Effects of treated wastewater irrigation on the establishment of young grapevines. Science of The Total Environment, 658: 485-492, 2018. 
ROCHA, S. A. et al. Growth and nutrition leaf of Eucalyptus sp. due to the use of different water qualities. Revista de Ciências Agrárias, 37: 141$151,2014$.

RODRIGUES, A. C. et al. Produção e nutrição mineral do maracujazeiro-amarelo em solo com biofertilizante supermagro e potássio. Revista Brasileira de Engenharia Agrícola e Ambiental, 13: 117-124, 2009.

SÁ, F. V. S. et al. Formação de mudas de maracujazeiro amarelo com diferentes doses de esterco caprino e volumes do substrato. Magistra, 26: 486- 494, 2014.

SÁ, F. V. S. et al. Growth and gas exchanges of papaya tree seedlings grown on alternative substrates. Científica, 44: 245-254, 2016.

SÁ, F. V. S. et al. Biofertilizantes na produção hidropônica de mudas de mamoeiro. Revista Verde de Agroecologia e Desenvolvimento Sustentável, 8: 109-116, 2013.

SANTOS, T. V. et al. Produção de mudas de maracujá amarelo com diferentes materiais refletores sobre bancada. Revista de Agricultura Neotropical, 4: 26-32, 2017.

SANTOS, V. A. et al. Formação de mudas de mamoeiro utilizando água residuária de laticínio nos substratos. Revista de Ciências Agroveterinárias, 17: 498-504, 2018.

SERRANO, L. A. L.; CATTANEO, L. F.; FERREGUETTI, G. A. Adubo de liberação lenta na produção de mudas de mamoeiro. Revista Brasileira de Fruticultura, 32: 874-883, 2010.

SILVA, E. A. et al. Adição de água residuária de laticínio em substrato para produção de mudas de maracujazeiro 'amarelo'. Revista Agrarian, 7: 4959, 2014.

TEDESCO, M. J. et al. Análise de solo, plantas e outros materiais. 1. ed. Porto Alegre, RS: UFGRS, 1995. $174 \mathrm{p}$. 